\title{
Clinical features, molecular genetics, and pathophysiology of dominant optic atrophy
}

\author{
Marcela Votruba, Anthony T Moore, Shomi S Bhattacharya
}

\begin{abstract}
Inherited optic neuropathies are a significant cause of childhood and adult blindness and dominant optic atrophy (DOA) is the most common form of autosomally inherited (non-glaucomatous) optic neuropathy. Patients with DOA present with an insidious onset of bilateral visual loss and they characteristically have temporal optic nerve pallor, centrocaecal visual field scotoma, and a colour vision deficit, which is frequently blue-yellow. Evidence from histological and electrophysiological studies suggests that the pathology is confined to the retinal ganglion cell. A gene for dominant optic atrophy (OPA1) has been mapped to chromosome 3q28-qter, and studies are under way to refine the genetic interval in which the gene lies, to map the region physically, and hence to clone the gene. A second locus for dominant optic atrophy has recently been shown to map to chromosome 18q12.212.3 near the Kidd blood group locus. The cloning of genes for dominant optic atrophy will provide important insights into the pathophysiology of the retinal ganglion cell in health and disease. These insights may prove to be of great value in the understanding of other primary ganglion cell diseases, such as the mitochondrially inherited Leber's hereditary optic neuropathy and other diseases associated with ganglion cell loss, such as glaucoma. ( $\mathcal{}$ Med Genet 1998;35:793-800)
\end{abstract}

Department of Molecular Genetics, Institute of Ophthalmology, University College London, Bath Street, London EC1V 9EL, UK M Votruba S S Bhattacharya

Moorfields Eye Hospital, City Road, London EC1V 2PD, UK

M Votruba

A T Moore

Correspondence to: Miss Votruba.
Keywords: dominant optic atrophy; clinical features; molecular genetics; OPA1

Dominant optic atrophy (DOA) is the most common form of autosomally inherited (nonglaucomatous) optic neuropathy. The incidence has been estimated at 1:50000 ${ }^{1}$ and prevalence as high as 1:10 $000 .^{2}$ It is named after the Danish ophthalmologist Poul Kjer, ${ }^{3}$ who clinically characterised 19 families in 1959. While evidence suggests that its highest prevalence may be in the Danish population, DOA has been described in pedigrees from France, ${ }^{4}$ the UK, ${ }^{56} \mathrm{Cuba}^{7}$ and the USA, ${ }^{8}$ although these pedigrees may all be of European descent. There are currently two known loci, an apparently more common one that maps to chromosome 3q28-qter (all of the pedigrees described above) and a much rarer locus on chromosome 18q12.2-12.3 ${ }^{9}$ (see below).

\section{Clinical features}

CLINICAL AND PATHOPHYSIOLOGICAL STUDIES OF DOA

Autosomal dominant optic atrophy is an autosomally inherited disorder characterised by optic nerve pallor and reduced visual acuity. ${ }^{10}$ First described clinically by Batten ${ }^{11}$ and later by $\mathrm{Kjer},{ }^{3}$ it typically presents in childhood with bilateral visual loss that is usually symmetrical, temporal optic nerve pallor, centrocaecal visual field scotoma, and colour vision deficit. ${ }^{12-15}$ The intraocular pressure is normal and the optic disc is not cupped. The clinical profile should be clearly distinguished from acute Leber's hereditary optic neuropathy, ${ }^{16}$ which has a sudden onset of visual loss in two eyes asynchronously and a later age of presentation (typically 18-35 years), although in the atrophic phase it may be very difficult to make this distinction without a family history. It may be more difficult to distinguish clinically dominant optic atrophy from X linked optic atrophy ${ }^{17}{ }^{18}$ without a family history. Recessively inherited optic atrophy is generally much more severe, presenting at the time of birth with nystagmus, ${ }^{19}$ and is rare in isolation. ${ }^{20}$ Other primary hereditary optic neuropathies, such as diabetes mellitus and insipidus with optic atrophy and deafness (DIDMOAD) ${ }^{21}$ and Behr's syndrome are multisystemic diseases.

Although $\mathrm{Kjer}^{3}$ reported mental retardation in up to $10 \%$ of his original patients this would appear to be exceptional. ${ }^{22}$ Sensorineural deafness has been associated with dominantly inherited optic atrophy in a number of pedigrees, ${ }^{23-28}$ but in none of these families has the disorder been mapped to the chromosome $3 q$ or $18 q$ loci. Other neurological abnormalities, such as ptosis and ophthalmoplegia ${ }^{28}$ and peripheral muscle wasting, ${ }^{29}$ have been reported but these pedigrees probably have a syndromic form of optic atrophy.

DOA has an insidious onset, presenting as young as 1 year of age ${ }^{30}$ or, more typically, between 4 and 6 years of age, although it may remain subclinical until early adult life. ${ }^{12}$ Some 
children are detected on routine preschool vision testing; $22.6 \%$ of the patients of Hoyt ${ }^{12}$ and $12.5 \%$ of those of Kline and Glaser ${ }^{30}$ had mild ophthalmological abnormalities which were only detected by screening, although more recent papers put this figure as low as $3.4 \%{ }^{31}$ The best corrected visual acuity ranges from $6 / 6$ to perception of light only, with a median of $6 / 36 .{ }^{31}$ Nystagmus is seen only if the visual acuity is severely impaired. Visual acuity is equal to or better than $6 / 12$ (that is, adequate for driving) in $14 \%$ of patients according to a recent study. ${ }^{31}$ It is extremely rare (penetrance 0.98 ) for an affected person to be asymptomatic and to have no optic nerve pallor (around $1 \%{ }^{31}$ ) or colour vision deficit.

Two forms of dominant optic atrophy have been described, ${ }^{32-34}$ infantile (or congenital) and juvenile. The infantile form was said to present with nystagmus. ${ }^{35}$ There was, however, disagreement for a long time as to whether two forms of the disease existed. ${ }^{1936}$ It is probable that these two conditions are part of a spectrum of clinical presentation, as there is considerable clinical inter- and intrafamilial heterogeneity, ${ }^{16}{ }^{31}$ both with respect to age at clinical diagnosis and visual acuity. The degree of severity of vision loss in one generation does not predict the severity in the next. ${ }^{12} 31$ The visual acuity typically ranges from $6 / 6$ to $6 / 60^{14}$ but, exceptionally, may be as poor as $6 / 120$, hand movements, or even perception of light only in very rare cases. There is evidence from longitudinal ${ }^{2}$ and cross sectional observations ${ }^{31}$ that visual acuity declines slowly with age in some families, but not in others. About one third of patients develop moderate to severe social or occupational handicap. ${ }^{10}$ Rapid decline in visual acuity in adult life has been reported, but it is rare. ${ }^{2}$ The vision loss is only occasionally asymmetrical.

The visual field defect is classically centrocaecal (fig 1A, B), central or paracentral, and often appears as a large defect (fig 1C) in patients with severe disease. There is a predominance of visual field defects in the superotemporal visual field, ${ }^{31} 37{ }^{38}$ but this has not been explained. The peripheral fields are usually full, but an inversion of red and blue isopters is seen, ${ }^{3}$ consistent with tritanopia.

The colour vision defect is often reported as an acquired blue-yellow loss or tritanopia, ${ }^{310}$ but many people have a generalised nonspecific dyschromatopsia. ${ }^{30}$ Others have described families with red-green colour defects. $^{39-41}$ More recently, assessment of patients from families that show evidence of linkage to the dominant optic atrophy locus on chromosome 3q28-qter with a battery of tests has shown that no patient examined displayed a truly isolated loss of tritan discrimination. ${ }^{42}$ There was even intrafamilial variation in colour axis discrimination. DOA may show some similarities on psychophysical testing to congenital tritanopia, ${ }^{43}$ but it should not be confused with the latter disorder.

The optic nerve appearance ranges from complete atrophy ${ }^{33}$ (fig 2A, B) through temporal pallor, ${ }^{374}$ (fig $2 \mathrm{C}$ ), to subtle pallor. ${ }^{3}$ According to one recent report, $55 \%$ of patients have subtle or temporal pallor and $44 \%$ have total atrophy of the optic nerve. ${ }^{31}$ The appearances are usually symmetrical. Beşt colour vision and least field loss have bee noted in patients with the least degree of clin $\frac{\mathbb{8}}{2}$ cal optic atrophy. ${ }^{31}$ The appearance of the nerve fibre layer in patients with DOA on scare ning laser ophthalmoscopy shows a diffuse los of retinal nerve fibres (unpublished data which contrasts to the wedge shaped segmental loss of nerve fibres seen in patients with glaucomatous optic atrophy. ${ }^{45}$ Magnetic res nance imaging of the optic nerves in patien with dominant optic atrophy shows a reduceg optic nerve sheath complex throughout the length of the intraorbital optic nerve with no signal abnormality and a clearly visible cer $\overrightarrow{\mathrm{r}_{-}}$ ebrospinal fluid (CSF) space. $^{46}{ }^{47}$ This cort trasts to appearances seen in the atrophic phase of Leber's hereditary optic neuropathy, where there is bright signal and typically no visible surrounding CSF seen, although the optis nerve sheath complex is also small. ${ }^{48}{ }^{49}$ It alsig contrasts with the features of tobacco-alcoh\&p neuropathy (where there are normal size optre sheath complexes and no signal abnormality) and optic neuritis (in which during the acuto phase there is CSF space loss and sign abnormality, and, in long standing cases, where there are variable, long lesions). ${ }^{51}$

Electrophysiology suggests that the defect in the ganglion cell layer of the retina. Many patients show an absent or delayed patter visually evoked potential (PVEP), ${ }^{52}$ showing that there is a conduction defect in the opto nerve. The pattern electroretinogram (PERG shows an abnormal ratio of waveforms (name the N95:P50 ratio), with reduction in the amplitude of the N95 waveform..$^{52-56}$ Since the PERG N95 component is postulated to be specific for the retinal ganglion cell, ${ }^{57}$ this find ing supports a ganglion cell origin for dom nant optic atrophy.

\section{Molecular genetics of dominant optic atrophy mapping to chromosome 3q28-qter}

MAPPING OF THE OPA1 GENE TO CHROMOSOME 3q28-qter AND GENETIC REFINEMENT

Genetic linkage studies in 1994 mapped dominant optic atrophy gene (OPA1, OMIM No $165500^{58}$ ) to chromosome $3 q 28-q$ ter $^{59}$ Th8 penetrance of the gene is high $(0.98) .{ }^{60} \mathrm{Thy}^{\mathrm{W}}$ disease gene was mapped initially to a 10-12 cM interval, but it has since been refined and fine mapped to a critical genetic interval of 1.9 cM flanked by markers D3S3669 and D3S3562 5162 (fig 3A). There is evidence for the overall predominance of one genet locus, ${ }^{463}$ although Seller et al ${ }^{64}$ identified $\frac{1}{2}$ pedigree that does not appear to map to chromosome 3q. Recently, a family has been reported ${ }^{9}$ that confirms the existence of genet heterogeneity (see below).

LINKAGE DISEQUILIBRIUM ANALYSIS

Analysis of pedigrees from the British Isles, unrelated on genealogy, has identified a founder effect. ${ }^{6566}$ Linkage disequilibrium multipoint analysis ${ }^{67}$ suggests that OPA1 lies 
A

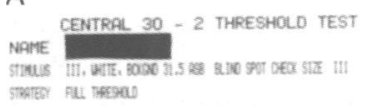

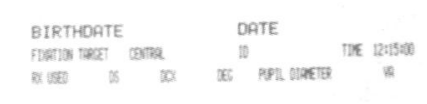

खis

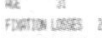

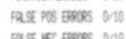

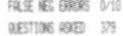

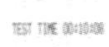

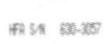
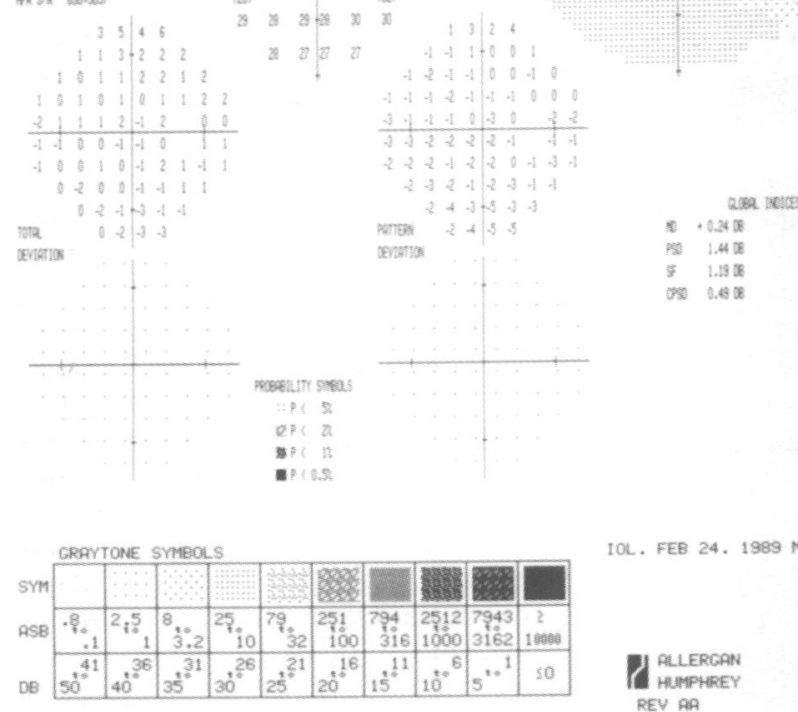

$5.0 .3 x$

$1.45 x$
$3 \quad 1.19 x$

$0.6 x$
1OL. FEB 24. 1989 MOOS. TI RLLERGAN
C

CENTREL $30-2$ THEESHOLO TEST

STIMULUS III, UHITE, BCKGNO 31.5 ASB NAME

Q. INO SPOT CHECK SIZE III

FIXATION TRRCET CEMTPQL TIME 15:56:24

STRPTEOY TAROET CEMTRAL

STRATEGY FULL THRESHOLO POPIL DIAMETER DS DAX DEO

RIGHT FIXATION LOSSES O/27 FALSE POS ERRORS O/20

FALSE NEC ERRORS 2/15

$\begin{array}{lll}\text { QUESTIONS ASKED } & 537 \\ 2.09 & 08\end{array}$

FLUCTUATION 2.09 DE

HFA SN $630-3057$

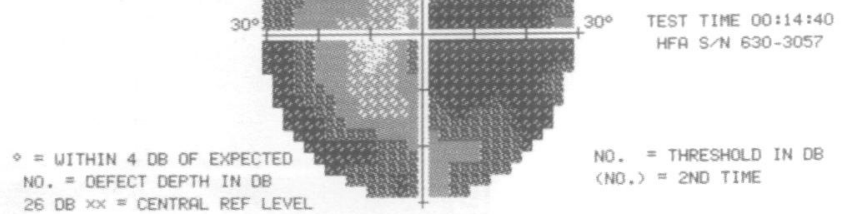

26. DB $X X=$ E CENTRQL REF LEVEL
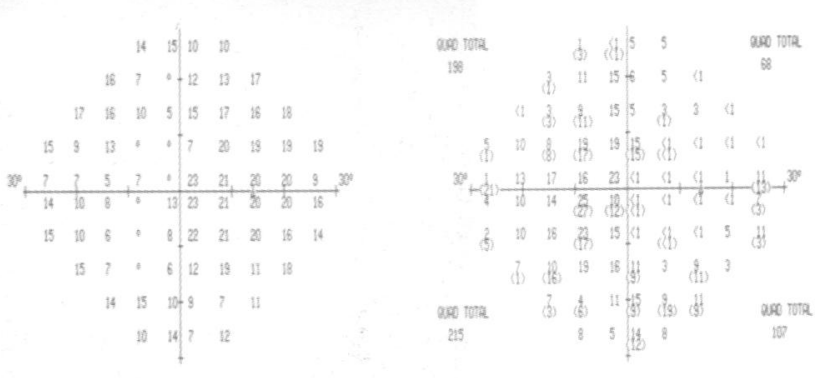

B CENTRPL $30-2$ THRESHOLD TEST

STIMULUS III, BLLE, BCKCND 31.5 ASE

SI IND SPOT OACCK SIE, BCKCND

FIXATION TARGET CENTRAL

STRATEGY FULL THRESHOLD

ID BIRTHDATE

DATE TIME 20:0?:56

PUPIL DIAMETER VA

RX USED DS DCX DEG

RIGHT

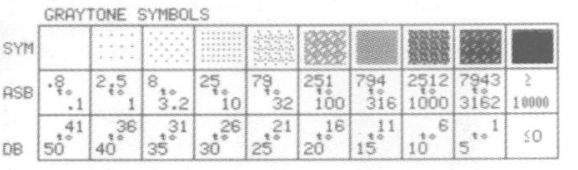

TOL. FEB 24. 1989 MOOS,

II RLLERGAR REV AQ

Figure 1 (A) Humphrey 30-2 visual field of right eye of a normal person, showing the physiological blind spot. (B) Humphrey 30-2 visual field of right eye of a patient with dominant optic atrophy mapping to chromosome 3q28-qter, showing a discrete centrocaecal scotoma. (C) Humphrey 30-2 visual field of right eye of a patient with dominant optic atrophy mapping to chromosome 3q28-qter, showing an extensive scotoma. 

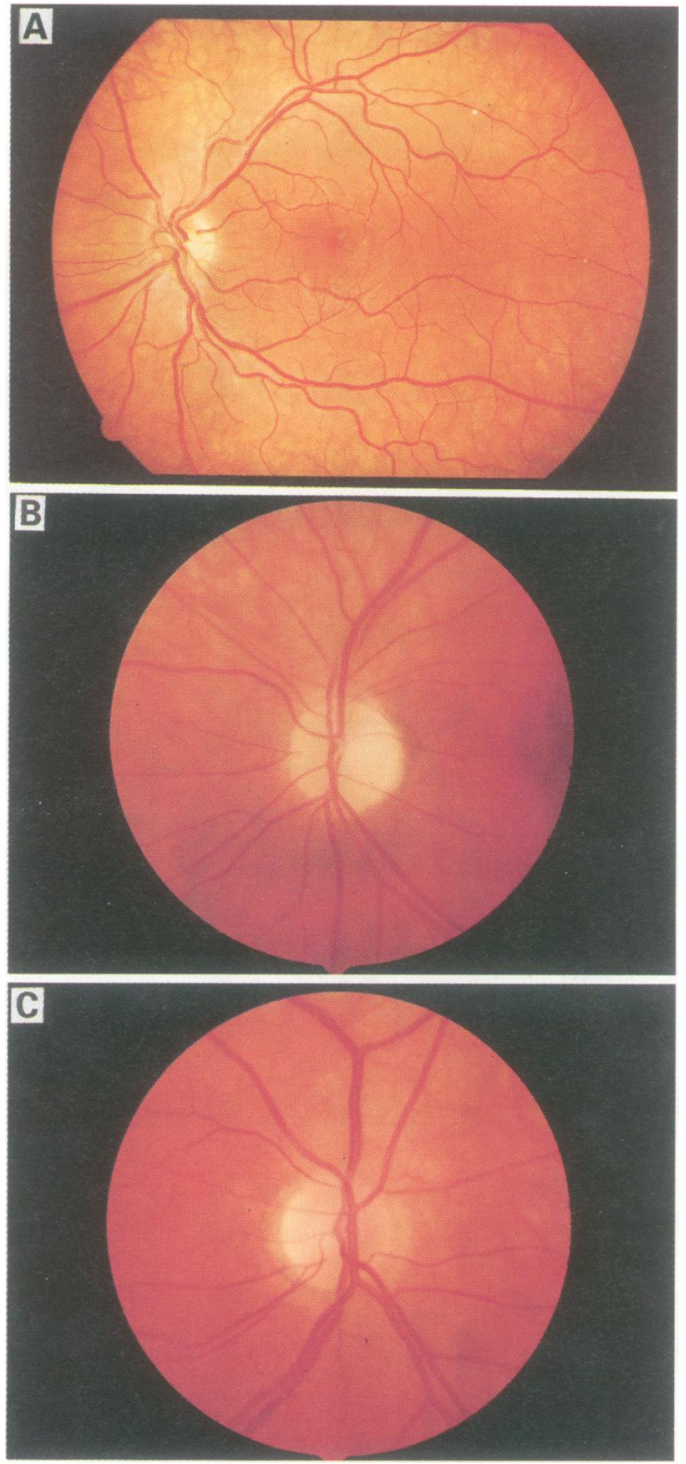

Figure 2 (A) Colour fundus photograph of left eye of a normal subject. (B) Colour fundus photograph of left eye of a patient with dominant optic atrophy mapping to chromosome 3q28-qter, showing total atrophy of the optic nerve. (C) Colour fundus photograph of right eye of a patient with dominant optic atrophy mapping to chromosome 3q28-qter, showing discrete temporal pallor of the optic nerve.

within about $400 \mathrm{~kb}$ either side of D3S1523. Haplotype data strongly suggest that OPA1 lies between the markers D3S1523 and D3S3642.

MOUSE MODEL

The report of a mouse mutant with optic atrophy offers the possibility that the cloning of the mouse gene may provide candidate genes for the human disorder and lead to the identification of the gene for the human DOA. An autosomal semidominant mouse mutation Bst/t shows a variable retinal phenotype, from complete absence of ganglion cells to near wild type numbers. ${ }^{68} 69$ The ganglion cell numbers appear to be reduced because of a failure of the ganglion cells to reach the optic nerve head in early development. ${ }^{69}$ The Bst gene is located on mouse chromosome 16 in a region of partial synteny to human chromosome 3 q 28 -qter, ${ }^{70}$ although the gene order does not appear to be completely conserved. The chromosomal position and phenotype make Bst/+ the best available model for human DOA.
PHYSICAL MAPPING AND CANDIDATE GENES

Physical mapping at the OPAl locus by the construction of a contig of YACs and PACS spanning the critical interval is under way. ${ }^{61} 71$ 22 Several genes and more than 42 ESTs are curg rently mapped to the wider OPA1 region (between D3S1601 and D3S1265), in tho SCIENCE96 database (http:

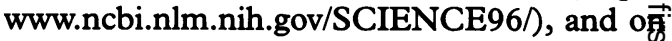
to the WC3.25 YAC contig (Whiteheag Institute/MIT Center for Genome Research E

One of these genes is HRY, the clone human homologue of the Drosophila segmenta甲 tion gene, hairy, which maps by in situ hybridio sation to $3 \mathrm{q} 28-\mathrm{q} 29 .{ }^{73}$ This gene encodes a basic helix-loop-helix transcription factor ${ }^{73}$ and it is $\$$ member of a family of mammalian neurodevel $\vec{F}$ opmental genes with Drosophila and ratक homologues. Currently, at least 14 transcrip tion factors are known to be required for eye् formation and mammalian eye development. ? HRY has been studied in gain of functio $\vec{P}$ studies ${ }^{76}$ and neuronal differentiation has been shown to be suppressed by targeted disruption of the gene in mice homozygous for the mutation. ${ }^{77} \mathrm{HRY}$ has been positioned onto th $\overrightarrow{\mathrm{g}}$ CEPH YAC $975 \mathrm{f} 4$ on a YAC contig that spand the OPA1 region. ${ }^{61} \mathrm{HRY}$ has been geneticall\% mapped to an interval between markers D3S3562 and D3S1305, ${ }^{78}$ which is outside the critical interval for OPA1. An association haso also been excluded by heteroduplex mutation detection (HET) and direct sequencing ${ }^{78}$ of the gene in its entirety.

An EST (stSG4566) highly similar to th: gene for the flavoprotein (fp) subunit of succid nate dehydrogenase (SDH2), a complex If mitochondrial respiratory enzyme, ${ }^{79}$ has als 9 been mapped loosely to the OPA1 intervale SDH deficiency has been reported in pheno? types including Leigh syndrome, ${ }^{79}$ Kearns Sayre syndrome, ${ }^{80}$ hypertrophic cardio myopathy, ${ }^{81}$ skeletal myopathy, ${ }^{82}$ and cerebellap ataxia and optic atrophy. ${ }^{79}$ However, SDH appears to be represented twice in the human genome, at chromosome $5 \mathrm{p} 15$ and $3 \mathrm{q} 29$, ang there is evidence from human-hamster somatie cell hybrids ${ }^{79}$ and unpublished data that the $\mathrm{SDH} 2$ locus on chromosome $3 \mathrm{q}$ is a pseudog ene (B Parfait, personal communication).

Three other ESTs corresponding to named genes map to the OPA1 critical interval. Thew్ are the gene transferrin receptor (TRP) (stSG13), platelet glycoprotein $\mathrm{V}$ precursof (L11238), and carboxypeptidase $\mathrm{N} 83 \mathrm{kD}$ chain (SHGC-12402). They are not immedi? ately attractive candidate genes for dominanto optic atrophy, but they have yet to be excluded? Lastly, DLG1, the gene for hDlg, encodes $₫$ membrane associated guanylate kinase homo $\mathbb{\Omega}$ logue (MAGUK), which belongs to a group of highly related proteins important in controlling epithelial and neuronal cell junctions, espee cially neuronal synapses. DLG1 has recentles. been mapped telomeric to the OPAl criticat interval ${ }^{83}$ and therefore excluded as a candidate gene for dominant optic atrophy.

The very rare early onset of DOA (clinically detectable in some people as young as 6 months of age) and the very slow progression 


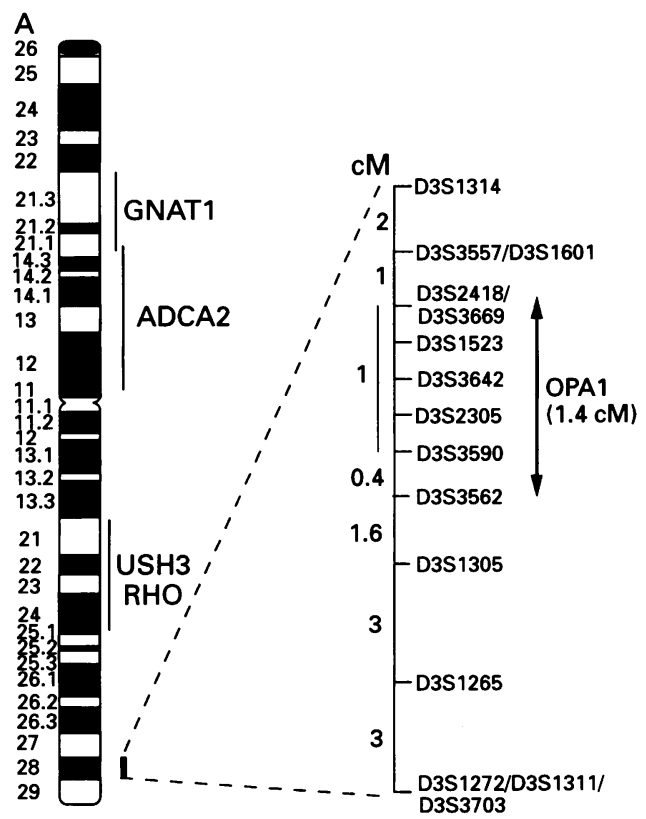

Figure 3 (A) Schematic diagram of chromosome 3, showing markers across the critical disease interval of dominant optic atrophy mapping to 3q28-qter (OPA1). (RHO=rhodopsin, GNAT1=dominant congenital stationary night blindness, Nougaret type, ADCA2=dominant spinocerebellar ataxia, USH3=recessive Usher syndrome, type 3.) (B) Schematic diagram of chromosome 18, showing the dominant optic atrophy locus at 18q12.2-12.3. (The markers shown all have statistically significant evidence of linkage, ${ }^{9}$ but it has not yet been possible to refine the genetic interval.) (CORD1=cone-rod dystrophy.)

suggest the possibility that a mutation in a neurodevelopmental gene may be involved. ${ }^{84} \mathrm{~A}$ family of transcription regulators, the POU-IV domain genes, has an important role in determining retinal ganglion cell numbers and is expressed differentially in retinal ganglion cell subtypes. ${ }^{85}$ The gene Brn-3b, a member of this class of genes, has been studied by targeted disruption in developing mouse retina ${ }^{86}$ Disruption leads in the homozygous state to a selective loss of $70 \%$ of retinal ganglion cells. The POU domain genes are excellent functional candidates for DOA, but to date none map in the OPAl critical interval. ${ }^{87}$

\section{Genetic heterogeneity within DOA}

Recently, linkage has been reported to a second locus on chromosome 18q12.2-12.39 (fig 3B). This linkage confirms the previous report of a large pedigree of German descent resident in the USA, which was linked to the Kidd blood group locus on chromosome 18 in $1983 .{ }^{60}$ Studies of the prevalence of the two loci will clarify their relative significance. Although few clinical data describing the chromosome 18 phenotype are available, there is evidence suggesting that the phenotype may be indistinguishable from the highly clinically heterogeneous phenotype of the chromosome 3q28-qter locus. In this respect, there appear to be great similarities to the phenotype of $\mathrm{X}$ linked optic atrophy (OPA2) that is closely linked to the

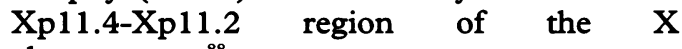
chromosome. $^{88}$

\section{Pathophysiology of dominant optic atrophy}

The pathophysiology of dominant optic atrophy is only very poorly understood. The site of pathology in dominant optic atrophy is thought to be the retinal ganglion cell, ${ }^{89}{ }_{90}^{90}$ histopath- ology shows that the outer retina appears to be normal and that there is a loss of retinal ganglion cells, primarily in the macula and in the papillomacular bundle of the optic nerve. The electrophysiological findings (above) confirm this view. It is far from clear if the disease is present subclinically in some people at the time of birth or if it only develops postpartum. It is possible that the gene for dominant optic atrophy is important in ganglion cell development, but it could also be a gene coding for an enzyme or for a structural protein.

Although few data are available from the direct study of the optic nerve in dominant optic atrophy, it is interesting to consider the parallels with the other major group of inherited optic neuropathies, the mitochondrial optic neuropathy found in Leber's optic atrophy (LHON). LHON is an inherited form of blindness in which a mutation in the mitochondrial genome (mtDNA) is the primary aetiological factor..$^{91}$ More than $95 \%$ of the LHON pedigrees of northern European descent have one of the three primary mitochondrial mutations at nucleotides 3460, 11778 , and $14484 .^{92}$ There are other rare primary mutations and mutations that are thought to have a secondary aetiological role. The optic neuropathy involves a loss of central vision owing to degeneration of the retinal ganglion cells and the optic nerve axons of the papillomacular bundle that subserve central vision. Although few histopathological studies of Leber's optic atrophy have been reported, some data are available. The optic nerve in a patient with genetically proven mutations at nucleotide positions 4160 and 14484 showed $1.2 \mu$ electron dense, double membrane bound inclusions (found to consist of calcium by electron probe analysis) in retinal ganglion cells. The optic nerve from this patient was homo- 
plasmic for mutations 4160 and $14484 .^{93}$ These features suggest that the optic nerve and inner retinal atrophy in LHON may be the result of a metabolic mitochondrial dysfunction leading to intramitochondrial calcification. It is hypothesised that the respiratory chain dysfunction leads to axoplasmic stasis and swelling, thereby blocking ganglion cell function and causing loss of vision..$^{94}$ It is also believed that, in some ganglion cells, this loss of function may be reversible, but in others the apoptotic cell death pathway is activated, leading to extensive degeneration of the retinal ganglion cell layer and optic nerve. It has been suggested that ATP deficiency may be a common mechanism for visual loss in LHON and also in toxic and deficiency optic neuropathies, ${ }^{95}$ and we believe that a respiratory chain defect may be associated with dominant optic atrophy because of the similarities to LHON.

Although the genes for dominant optic atrophy have yet to be cloned, it is possible to speculate that the gene may be a nuclear encoded gene involved in the oxidative phosphorylation (OXPHOS) pathway, given the clinical and morphological similarities between dominant optic atrophy and LHON. Of the many enzymes involved in the OXPHOS chain of reactions, approximately one third are encoded by nuclear genes and two thirds are encoded by mitochondrial genes. Nuclear genes encoding mitochondrial enzymes may be duplicated in the genome. Thus it is possible that a mutation in either of these genomes can lead to a disruption in the OXPHOS cascade.

\section{Genetic counselling in dominant optic atrophy}

Although the penetrance of dominant optic atrophy is high $(0.98),{ }^{59}$ there is considerable intra- and interfamilial phenotypic heterogeneity. The majority of patients present in early to mid childhood and the clinical diagnosis is generally reliable from 6 years of age and above, except in rare cases. As there are some people who may only be very mildly affected, it is advisable to include colour vision assessment and even electrodiagnostic testing in cases where there is any doubt, in addition to the full clinical examination. A multidisciplinary approach to the diagnosis and management of these patients is helpful, involving both clinical ophthalmologists and geneticists, electrodiagnostic services, low vision specialists, and educational advisors.

The clinician may be faced with one of two difficult situations: either an apparently sporadic person who presents with nonprogressive optic atrophy and normal neuroimaging, or a person uncertain of his clinical status from a family known to be affected by dominant optic atrophy. In the first situation, it is important to examine all family members fully, as relatives may be only mildly affected, and establish if there is a disease pedigree and, if so, what the mode of transmission is. In the second situation, one may need to include colour vision and electrophysiology in the full clinical assessment of the patient in order to be able to make a diagnosis.

Genetic counselling in this condition cure rently relies on conventional risk assessment, in the absence of a diagnostic test. Linkage and haplotype analysis in larger pedigrees can pro vide evidence of a strong likelihood that a pere son carries the disease gene, but may be inconclusive. This is even more of a problem if ther is genetic heterogeneity, as hereditary diseaseo resulting from mutations at different loci mas be indistinguishable phenotypically. In the respect, the position of dominant optic atroph is akin to the situation in autosomal dominan polycystic kidney disease, where PKD1 is said. to account for $85 \%$ of patients, PKD2 for $10 \%$ and an as yet unlinked locus (PKD3) for a few remaining families. ${ }^{96}$ Therefore, at present, the assignment of status in most families must rel्ञ upon clinical findings.

It is not possible to predict with any certaint the degree of severity of visual handicap an $\$$ long term prognosis of a member of a familso from one generation to the next. However, it is true to say that the severity of the condition by the age of adolescence reflects the overall levet of visual function to be expected throughout most of the patient's adult life. There is evidence for slow deterioration in visual acuity particularly reported by patients as the approach later middle age, which is not entirelgo explained by refractive changes. This deteriora tion has been documented to be particularle marked in some families. The reasons for the $\frac{15}{5}$ are not known, but may relate to the nature type of mutation in those families.

\section{Future prospects}

The gene that causes dominant optic atroph OPA1, mapping to chromosome 3q28-qter, is likely to be cloned within the next few years Given the abundant clinical heterogeneity of the condition, both within and between families, it will be fascinating to assess the genotype-phenotype correlations once muta? tions in the gene have been identified. While different mutations in the OPA1 gene in unres lated families (allelic heterogeneity) woule account for interfamilial variation, intrafamiliā variation could not be explained in thrs manner. Other factors, including age, genetis background, the modifying effects of other genes involved in retinal and ganglion ce⿺𠃊 development, physiological and environmentif factors, may be relevant. The presence of a sec ond locus on chromosome 18, so far reported in one pedigree, has recently been confirmed but no data on genotype-phenotype correlक tions are yet available. This second locus likely to account for a smaller proportion of cases affected by autosomal dominant optic atrophy than the chromosome $3 \mathrm{q}$ locue because it has not been reported so far in the large collections of families studied by othe workers to date, who have generally found that all the families studied mapped to chromosome 3q.

The authors wish to thank The Guide Dogs for the Blind Association, UK and The Wellcome Trust for financial support. 
(MV is a Vision Research Training Fellow (049403/Z/96/Z/ WRE/MK/JAT).

1 Lyle WM. Genetic risks. Waterloo, Ontario: University of Waterloo Press, 1990.

2 Kjer B, Eiberg H, Kjer P, Rosenberg T. Dominant optic atrophy mapped to chromosome $3 \mathrm{q}$ region. II. Clinical and epidemiological aspects. Acta Ophthalmol Scand 1996;74:37 .

3 Kjer P. Infantile optic atrophy with dominant mode of inheritance: a clinical and genetic study of 19 Danish families. Acta Ophthalmol Scand 1959;37(suppl 54):1-146.

4 Bonneau D, Souied E, Gerber S, et al. No evidence of genetic heterogeneity in dominant optic atrophy. $f \mathrm{Med}$ Genet 1995;32:951-3.

5 Votruba M, Moore AT, Bhattacharya SS. Genetic refinement of dominant optic atrophy (OPA1) locus to within a $2 \mathrm{cM}$ interval of chromosome 3q. $\mathcal{F}$ Med Genet 1997;34: 117-21.

6 Johnston RL, Burdon MA, Spalton DJ, Bryant SP, Behnam JT, Seller MJ. Dominant optic atrophy, Kjer type: linkage analysis and clinical features in a large British pedigree. Arch Ophthalmol 1997;115:100-3.

7 Lunkes A, Hartung U, Magarino C, et al. Refinement of the OPA1 gene locus on chromosome $3 q 28-q 29$ to a region of $2-8$ centiMorgans in one Cuban family with autosomal
dominant optic atrophy type Kjer. Am $\mathcal{F}$ Hum Genet 1995; dominant

8 Brown J, Fingert JH, Taylor CM, Lake M, Sheffield VC Stone EM. Clinical and genetic analysis of a family affected with dominant optic atrophy (OPA1). Arch Ophthalmol 1997;115:95-9.

9 Kerrison JB, Arnould V, Barmada MM, et al. Autosomal dominant optic atrophy pedigree linked to chromosome 18q12.2-12.3. Invest Ophthalmol Vis Sci 1998;39:2338.

10 Eliott MD, Traboulsi EI, Maumenee IH. Visual prognosis in autosomal dominant optic atrophy (Kjer type). Am $₹$ Ophthalmol 1993;115:360-7.

11 Batten B. A family suffering from hereditary optic atrophy Trans Ophthalmol Soc UK 1896;16:125.

12 Hoyt CS. Autosomal dominant optic atrophy: a spectrum of disability. Ophthalmology 1980;87:245-51.

13 Caldwell JBH, Howard RO, Riggs LA. Dominant juvenile optic atrophy: a study of two families and review of the hereditary disease in childhood. Arch Ophthalmol 1971;85: 133-47.

14 Smith DP. Diagnostic criteria in dominantly inherited juvenile optic atrophy: a report of three new families. $A m \mathcal{J}$ Optom Physiol Optics 1972;49:183-200.

15 Jaeger W. Diagnosis of dominant infantile optic atrophy in early childhood. Ophthal Paediatr Genet 1988;9:7-11.

16 Jacobson DM, Stone EM. Difficulty differentiating Leber's from dominant optic neuropathy in a patient with remote visual loss. 7 Clin Neuro-Ophthalmol 1991;11:152-7.

17 Volker-Dieben HJ, Lith GHMV, Went LN, Klawer JW, Staa A, Mol ECDV-d. A family with sex linked optic atrophy (ophthalmological and neurological aspects). Doc Ophthalmol 1974;37:307-26.

18 Went LN, Mol ECDV-d, Volker-Dieben HJ. A family with apparently sex-linked optic atrophy. $f$ Med Genet 1975;12: 94-8.

19 Waardenburg PJ. Different types of hereditary optic atrophy. Acta Genet Statist Med 1957;7:287-90.

20 Moller HU. Recessively inherited, simple optic atrophy does it exist? Ophthal Paediatr Genet 1992;13:31-2.

21 Wolfram DJ, Wagener HP. Diabetes mellitus and simple optic atrophy among siblings: report of four cases. Mayo Clin Proc 1938;13:715-18.

22 Bitoun P, Martin-Pont B, Tamboise E, Gaudelus J. Optic atrophy, microcephaly, mental retardation and mosaic variegated aneuploidy: a human mitotic mutation. Ann Genet 1994;37:75-7.

23 Amemiya T, Honda A. A family with optic atrophy and congenital hearing loss. Ophthal Genet 1994;15:87-93.

24 Iwashita $H$. Optic atrophy, neural deafness and distal neurogenic amyotrophy. Arch Neurol 1970;22:357-64

25 Koningsmark BW, Knox DL, Hussels IE, Moses H. Dominant congenital deafness and progressive optic nerve atrophy. Arch Ophthalmol 1974;91:99-103.

26 Meire F, Laey JJD, Bie SD, Staey MV, Matton MT. Dominant optic nerve atrophy with progressive hearing loss and chronic progressive external ophthalmoplegia (CPEO). Ophthal Paediatr Genet 1985;5:91-7.

27 Mets MB, Mhoon E. Probable autosomal dominant optic atrophy with hearing loss. Ophthal Paediatr Genet 1985;5 $85-9$

28 Treft RL, Sanborn GE, Carey J, et al. Dominant optic atrophy, deafness, ptosis, ophthalmoplegia, dystaxia and myopathy: a new syndrome. Ophthalmology 1984;91:90815

29 Sorkin JA, Magauran RG, Small KW. Dominant optic atrophy and peripheral muscle wasting: a pedigree. Invest $O$ phthalmol Vis Sci 1994;35:1544.

30 Kline LB, Glaser JS. Dominant optic atrophy. The clinical profile. Arch Ophthalmol 1979;97:1680-6.

31 Votruba M, Fitzke FW, Holder GE, Carter A, Bhattacharya SS, Moore AT. Clinical features in affected individuals from 21 pedigrees with dominant optic atrophy. Arch Ophthalmol 1998;116:351-8.

32 Jaeger W. Hereditary optic atrophies in childhood. $\mathcal{f}$ Genet Hum 1966;15:312-21.

33 Lodberg CV, Lund A. Hereditary optic atrophy with dominant transmission: three Danish families. Acta Ophthalmol 1970;28:437-68.
34 Kjer P. Hereditary infantile optic atrophy with dominant transmission (preliminary report). Dan Med Bull 1965;3: 135-41.

35 Thompson AH, Cashell GTW. Pedigree of congenital optic atrophy embracing sixteen affected cases in six generations. Proc $R$ Soc Med 1934;28:1415-25.

36 Francois J. Heredity in ophthalmology. St Louis: C V Mosby, 1961

37 Manchester PT, Calhoun J. Dominant hereditary optic atrophy with bitemporal field defects. Arch Ophthalmol 1958;60:479-84.

38 Smith DP. The assessment of acquired dyschromatopsia and clinical investigation of the acquired tritan defect in dominantly inherited juvenile optic atrophy. $A m \mathcal{F}$ Optom Physiol Optics 1972;49:574-88.

39 Kok-van-Alphen CC. Four families with the dominant infantile form of optic nerve atrophy. Acta Ophthalmol 1970;48:905-16.

40 Jeager W, Fruh D, Lauer HJ. Types of acquired colour deficiencies caused by autosomal-dominant infantile optic atrophy. In: Verriest G, ed. Acquired colour vision deficiencies. Modern problems in ophthalmology. Vol 11. Basel: Karger, 1972:145-7.

41 Mantyjarvi MI, Nerdrum K, Tuppurainen K. Colour vision in dominant optic atrophy. $\mathcal{f}$ Clin Neuro-Opthalmol 1992;12:98-103.

42 Simunovic M, Votruba M, Regan B, Mollon J. Residual colour discrimination in low vision patients: results of a new test in dominant optic atrophy. Vision Res (in press).

43 Krill AE, Smith VC, Pokorny J. Similarities between congenital tritan defects and dominant optic-nerve atrophy: coincidence or identity? F Optom Soc Am 1970;60: $1132-9$.

44 Scott JG. Hereditary optic atrophy with dominant transmission and early onset. Br f Ophthalmol 1941;25:461-79.

45 Jonas JB, Schiro D. Localized wedge-shaped defects of the retinal nerve-fibre layer in glaucoma. $\mathrm{Br} \mathcal{F}$ Ophthalmol 1994;78:285-90.

46 Moseley IF, Votruba M, Leary S, et al. MRI of the optic nerve in patients with autosomal dominant optic atrophy. Neuroradiology 1997;39:S55.

47 Votruba M, Leary S, Losseff N, Moore AT, Miller S, Moseley I. MRI of the intraorbital optic nerve in patients with autosomal dominant optic atrophy. $\mathcal{F}$ Neuro-Ophthalmol (in press)

48 Kermode AG, Moseley IF, Kendal BE, Miller DH, Macmanus DG, McDonald WI. Magnetic resonance imaging in Leber's optic neuropathy. $\mathcal{f}$ Neurol Neurosurg Psychiatry 1989;52:671-4.

49 Gass A, Barker GJ, MacManus D, et al. High resolution magnetic resonance imaging of the anterior visual pathway in patients with optic neuropathies using fast spin echo and phased array local coils. $\mathcal{f}$ Neurol Neurosurg Psychiatry 1995;58:562-9.

50 Kermode A, Miller DH. MRI of tobacco-alcohol amblyopia. F Neurol Neurosurg Psychiatry 1989;52:1447.

51 Miller DH, Newton MR, Poel JCVd. Magnetic resonance imaging of the optic nerve in optic neuritis. Neurology 1988;38:175-9.

52 Holder GE, Votruba M, Carter AC, Bhattacharya SS, Fitzke FW, Moore AT. Electrophysiological findings in dominant optic atrophy (DOA) linking to the OPA1 locus on chromosome 3q 28-qter. Doc Ophthalmol (in press).

53 Harding GFA, Crews SJ, Pitts SM. Psychophysical and visual evoked potential findings in hereditary optic atrophy. Trans Ophthalmol Soc UK 1979;99:96-102.

54 Holder GE. Significance of abnormal pattern electroretinography in anterior visual pathway dysfunction. $\mathrm{Br} \mathcal{F} \mathrm{Oph}-$ thalmol 1987;71:166-71.

55 Holder GE, Votruba M, Carter AC, Bhattacharya SS, Fitzke FW, Moore AT. Dominant optic atrophy (DOA): clinical, genetic and electrophysiological findings. Electroencephalogr Clin Neurophysiol (in press).

56 Berninger TA, Jaeger W, Krastel $\mathrm{H}$. Electrophysiology and colour perimetry in dominant infantile optic atrophy. $\mathrm{Br} f$ Ophthalmol 1991;75:49-52.

57 Ryan S, Arden GB. Electrophysiological discrimination between retinal and optic nerve disorders. Doc Ophthalmol 1988;68:247-55

58 McKusick VA. Mendelian inheritance in man. 10th ed. Baltimore: The Johns Hopkins University Press, 1992.

59 Eiberg H, Kjer B, Kjer P, Rosenberg T. Dominant optic atrophy (OPA1) mapped to chromosome $3 \mathrm{~g}$ region. I. Linkage analysis. Hum Mol Genet 1994;3:977-80.

60 Kivlin JD, Lovrien EW, Bishop DT, Maumenee IH. Linkage analysis in dominant optic atrophy. Am $\mathcal{F}$ Hum Genet 1983; 35:1190-5.

61 Jonasdottir A, Eiberg H, Kjer B, Kjer P, Rosenberg T. Refinement of the dominant optic atrophy locus (OPA1) to a 1.4-cM interval on chromosome $3 q 28-3 q 29$, within a 3-Mb YAC contig. Hum Genet 1997;99:115-20.

62 Stoilova D, Child A, Desai SP, Sarfarazi M. Refinement of the locus for autosomal dominant juvenile optic atrophy to a 2 cM region on 3q28. Ophthal Genet 1997;18:1-6.

63 Votruba M, Bhattacharya SS, Moore AT. No evidence for genetic heterogeneity in autosomal dominant optic atrophy. Vision Res 1995;35:S240.

64 Seller MJ, Benham JT, Lewis CM, Johnston RL, Burdon MA, Spalton DJ. Linkage studies in dominant optic atrophy, Kjer type: possible evidence for heterogeneity. $\mathcal{F}$ Med Genet 1997;34:967-72

65 Votruba M, Moore AT, Bhattacharya SS. Demonstration of a founder effect and linkage disequilibrium mapping in the 
refinement of the dominant optic atrophy locus. Am $\mathfrak{f}$ Hum Genet 1997;61:1746.

66 Votruba M, Moore AT, Bhattacharya SS. Demonstration of a founder effect and fine mapping of dominant optic atrophy locus on 3q28-qter by linkage disequilibrium method. Hum Genet 1998;102:79-86.

67 Terwilliger JT, Ott J. Handbook of human genetic linkage. Baltimore: The Johns Hopkins University Press, 1994.

68 Rice DS, Williams RW, Davisson MT, Harris B, Goldowit D. A new mutant phenotype of retinal ganglion cell dysgenesis discovered in the mouse. Society of Neuroscience Abstracts 1993;19:51.

69 Rice DS, Tang Q, Williams RW, Harris BS, Davisson MT, Goldowitz D. Decreased retinal ganglion cell number and misdirected axon growth associated with fissure defects in Bst/t mutant mice. Invest Ophthalmol Vis Sci 1997;38: 2112-24.

70 Rice DS, Williams RW, Ward-Bailey $P$, et al. Mapping the Bst mutation on mouse chromosome 16: a model for human optic atrophy. Mamm Genome 1995;6:546-8.

71 Churchill AJ, Lench NJ, Markham AF. Physical mapping of the dominant optic atrophy gene, OPA1. Am $₹$ Hum Genet 1997;61:A232.

72 Votruba M, Moore AT, Bhattacharya SS. Physical mapping of the OPAl region and linkage disequilibrium analysis in of the OPAl region and linkage disequilibrium analysis in
dominant optic atrophy. Invest Ophthalmol Vis Sci 1998;39: dominan.

73 Feder JN, Li L, Jan LY, Jan YN. Genomic cloning and chromosomal localization of $H R Y$, the human homolog to the Drosophila segmentation gene, hairy. Genomics 1994;20:56 61.

74 Feder JN, Jan LY, Jan YN. A rat gene with sequence homology to the Drosophila gene hairy is rapidly induced by ogy to the Drosophila gene hairy is rapidy induced by growth factors known to influe

75 Freund CL, Horsford DJ, Mciness RR. Transcription factor genes and the developing eye: a genetic perspective. Hum Mol Genet 1996;5:1471-88.

76 Tomita $\mathrm{K}$, Ishibashi $\mathrm{M}, \mathrm{Nakahara} \mathrm{K}$, et al. Mammalian hairy and enhancer of Split homolog 1 regulates differentiation of retinal neurons and is essential for eye morphogenesis. Neuron 1996;16:723-34.

77 Ishibashi M, Ang SL, Shiota K, Nakanishi S, Kageyama R, Guillemont $\mathrm{F}$. Targeted disruption of mammalian hairy and Enhancer of Split Homolog-1 (HES-1) leads to up-regulation Enhancer of Split Homolog-1 (HES-1) leads to up-regulation and severe neural tube defects. Genes Dev 1995;9:3136-48.

78 Votruba M, Payne A, Moore AT, Bhattacharya SS Dominant optic atrophy: exclusion and fine genetic mapping of the candidate gene, HRY. Mamm Genome (in press).

79 Bourgeron T, Rustin P, Chretien D, et al. Mutation of a nuclear succinate dehydrogenase gene results in mitochondrial respiratory chain deficiency. Nat Genet 1995;11:144-
80 Rivner MD, Shamsnia M, Swift TR, et al. Kearns-Sayre syndrome and complex II deficiency. Neurology 1989;39. 693-6.

81 Rustin $\mathrm{P}$, Lebidois J, Chretien D, et al. The investigation of respiratory chain disorders in heart using endomyocardiat biopsies. F Inherit Metab Dis 1993;16:541-4.

82 Reichmann H, Angelini C. Single muscle fibre analyses in $\mathbb{D}$ brothers with succinate dehydrogenase deficiency. EuQ Neurol 1993;34:95-8.

83 Alexander C, Stathakis DG, Lin L, et al. Fine scale mappin places DLG1, the gene encoding $\mathrm{hDlg}$, telomeric to the: OPAl candidate region. Mamm Genome 1997;8:795-6.

84 Xiang $M$, Zhou $H$, Nathans J. Molecular biology of retina $\overline{\bar{b}}$ ganglion cells. Proc Natl Acad Sci USA 1996;93:596-601

85 Xiang M, Zhou L, Macke J, et al. The Brn-3 family of POU domian factors: primary structure, binding specificity, an $\overline{\mathbb{P}}$ expression in subsets of retinal ganglion cells and somatos sensory neurons. F Neurosci 1995;15:4762-85.

86 Gan L, Xiang M, Zhou L, Wagner DS, Klein WH, Nathan® J. POU domain factor Brn-3b is required for the development of a large set of retinal ganglion cells. Pro\& Natl Acad Sci USA 1996;93:3920-5.

87 Xia YR, Andersen B, Mehrabian M, et al. Chromosomal organization of mammalian POU domain factors. Genomics 1993;18:126-30.

88 Assink JM, Tijmes NT, Brink JBt, et al. A gene for X-linked optic atrophy is closely linked to the $\mathrm{Xp} 11.4-\mathrm{Xp} 11.2$ region of the X chromosome. Am F Hum Genet 1997;61:934-9.

89 Johnston PB, Gaster RN, Smith VC, Tripathi RC. clinicopathological study of autosomal dominant optic atrophy. Am f Ophthalmol 1979;88:868-75.

$90 \mathrm{Kjer}$ P. Histopathology of eye, optic nerve and brain in a case of dominant optic atrophy. Acta Ophthalmol 1983;61:300€0 12.

91 Howell N. Leber hereditary optic neuropathy: mitochon drial mutations and degeneration of the optic nerve. Vision Res 1997;37:3495-507.

92 Mackey DA, Oostra $\mathrm{R}$, Rosenberg $\mathrm{T}$, et al. Primar pathogenic $\mathrm{mtDNA}$ mutations in multigeneration ped 5 grees with Leber hereditary optic neuropathy. Am $\mathcal{F}$ Hur grees with Leber hereditary optic neuropathy. Am $\mathcal{F}$ Hent
Genet 1996;59:481-5.

93 Kerrison JB, Howell N, Miller NR, Hirst L, Green WR. Leber hereditary optic neuropathy. Electron microscops and molecular genetic analysis of a case. Ophthalmologes 1995;102:1509-16.

94 Howell N. Leber hereditary optic neuropathy: how do mito chondrial DNA mutations cause degeneration of the optif nerve? f Bioenerg Biomembr 1997;29:165-73.

95 Rizzo JF. Adenosine triphosphate deficiency: a genre optic neuropathy. Neurology 1995;45:11-16.

96 Sessa A, Ghiggeri GM, Turco AE. Autosomal dominan polycystic kidney disease: clinical and genetic aspects. Nephrol 1997;10:295-310. 